\title{
PENGEMBANGAN MULTIMEDIA PEMBELAJARAN FOTOGRAFI BERBASIS ECOHISTORY UNTUK MENUMBUHKAN KARAKTER PEDULI LINGKUNGAN
}

\author{
Handini Arga Damar Rani * \& Nuryanti \\ Universitas Ivet 1, Universitas Ivet 2 \\ *hani.arga@gmail.com
}

\begin{abstract}
ABSTRAK
Penelitian ini merupakan penelitian pengembangan yang berfokus dalam mengembangkan multimedia pembelajaran berbasis ecohistory untuk menumbuhkan sikap peduli lingkungan. Tujuan dari penelitian ini adalah untuk menghasilkan produk berupa multimedia fotografi berbasis ecohistory yang valid dan reliabel untuk menumbuhkan sikap peduli lingkungan pada diri mahasiswa. Subjek validasi produk adalah duaorang ahli yaitu ahli materi dan ahli media. Sedangkan subjek uji coba produk multimedia pembelajaran berbasis ecohistory dalam penelitian pengembangan ini adalah mahasiswa program studi Pendidikan Informatika Universitas Ivet. Penelitian ini menggunakan rancangan pengembangan model 4D yaitu define, design, develop dan disseminate. Metode pengumpulan data dilakukan dengan validasi ahli, observasi dan angket. Skor hasil validasi ahli dan angket dianalisis dengan metode deskriptif. Data hasil penelitian menunjukkan bahwa multimedia yang dikembangkan tergolong valid dengan skor hasil validasi 3,62 dalam skala 1-4; dan 89,9\% mahasiswa memberikan respon positif terhadap multimedia yang dikembangkan.
\end{abstract}

Kata kunci: multimedia, fotografi, ecohistory, peduli lingkungan

\begin{abstract}
This research is development research focused on developing ecohistory based photography multimedia to foster the environmental awareness among the under graduates students. The aims of the research are to produce a ecohistory-based photography multimedia that is valid and reliable to foster the environmental awareness. The validation subject of this study are media and materials expert. The population of the research is the undergraduate students of Informatic Education Universitas IVET Semarang. Design of development research uses 4-D model consist of define, design, develop and disseminate. The method of obtaining the data used is expert validation, observation and responses questionaire. The validation score and questionaire are analysis by descriptive method. This research reveals that the validity of the ecohistory based photography multimedia can be categorize valid with validation score 3,65 in cardinal number 1-4; and $89,9 \%$ of undergraduates students gives positif responses to the ecohistory based photography multimedia. Keywords: multimedia, photography, ecohistory, environmental awareness
\end{abstract}




\section{PENDAHULUAN}

Kehidupan manusia tidak terlepas dari interaksi dengan lingkungan sekitar baik lingkungan fisik maupun sosial. Pesatnya perkembangan IPTEK di berbagai bidang kehidupan telah memberikan dampak positif dan negatif pada lingkungan. Salah satu dampak negative dari perkembangan IPTEK adalah terjadinya kerusakan lingkungan hidup yang pada akhirnya akan berakibat pada penurunan kualitas lingkungan.

Masalah yang terjadi pada lingkungan saat ini bukanlah suatu kebetulan atau akibat dari kegiatan yang sesaat. Masalah lingkungan yang ada merupakan hasil proses terus menerus dari generasi ke generasi selanjutnya. Banyak generasi muda yang ada saat ini tidak paham dan terus mewarisi kesalahan- kesalahan yang menyebabkan kerusakan lingkungan dari generasi terdahulu. Generasi muda saat ini belum banyak mempelajari betapa indahnya lingkungan yang ada di masa lalu, jauh sebelum mereka dilahirkan jika dibandingkan dengan apa yang terjadi pada masa kini.

Perilaku manusia terhadap kondisi lingkungan yang cenderung tidak peduli, maka mengubah perilaku menjadi prioritas utama dalam mengatasi krisis lingkungan (Gunawan, 2016). Hal ini menunjukkan bahwa masih banyak masyarakat yang tidak peduli terhadap lingkungan alam nya, dan ini memperlihatkan karakter kepedulian lingkungan yang semakin memprihatinkan.

Karakter peduli lingkungan didefinisikan sebagai sikap dan tindakan yang selalu berupaya mencegah kerusakan pada lingkungan alam di sekitarnya dan mengembangkan upaya-upaya untuk memperbaiki kerusakan alam yang sudah terjadi. Definisi lain dari karakter peduli lingkungan adalah suatu sikap yang dimiliki oleh seseorang yang berupaya untuk memperbaiki dan mengelola lingkungan sekitar secara benar sehingga lingkungan dapat dinikmati secara terus menerus tanpa merusak keadaannya, serta menjaga dan melestarikan sehingga ada manfaat yang berkesinambungan (Purwanti, 2017).

Berdasarkan (Kaiser et al. 2007), perilaku peduli lingkungan memiliki enam indikator, yaitu penghematan energy, mobilitas dan transportasi, pencegahan limbah, daur ulang, konsumersime, perilaku yang bertujuan untuk melestarikan alam. Ke-enam inidikator ini dapat digunakan untuk mengukur seberapa besar perilaku peduli lingkungan dari masingmasing individu.

Dengan mempelajari sejarah perkembangan ekosistem (Ecohistory) diharapkan generasi muda khususnya mahasiswa mampu merefleksi perilakunya selama ini dengan berkaca pada nilai-nilai luhur yang dimiliki oleh pendahulu mereka pada masa lalu sehingga mereka dapat mengambil keputusan tepat antara baik dan buruknya dalam memperlakukan lingkungan sekitar.

Hasil penelitian pendahuluan yang merupakan tahap awal dari penelitian ini yaitu dengan menggunakan instrumen selfassessment untuk mengukur komponen sikap peduli lingkungan mahasiswa Universitas Ivet yang terdiri atas aspek afektif, kognitif dan konatif menunjukkan bahwa aspek afektif dan kognitif mahasiswa tergolong tinggi namun pada aspek konatif tergolong sedang. Nilai konatif yang tergolong sedang mengindikasikan bahwa siswa memiliki pengetahuan dan kecenderungan pro terhadap lingkungan namun memiliki kecenderungan belum menerapkan sepenuhnya perilaku peduli lingkungan tersebut dalam kehidupan (Rani, 2019).

Berdasarkan fakta di atas perlu adanya integrasi nilai-nilai sikap peduli lingkungan pada pembelajaran mata kuliah selain bidang ekologi dan lingkungan. Hal tersebut dikarenakan pada kenyataannya masih terdapat anggapan bahawa nilai-nilai 
sikap peduli lingkungan hanya dapat di integrasikan dengan mata kuliah yang berhubungan dengan bidang ekologi dan lingkungan. Pembelajaran berbasis ecohistory pada mata kuliah fotografi mengintegrasikan berbagai disiplin ilmu antara lain informatika, IPA dan sejarah.

Melalui mata kuliah fotografi misalnya, mahasiswa dapat mengabadikan fenomena yang terjadi pada saat ini dan membandingkannya dengan fenomena lingkungan yang ada pada masa lalu dan menganalisisnya sehingga dapat mengetahui peran manusia di dalam perubahan yang terjadi. Hal tersebut dikarenaan peran dari fotografi itu sendiri dimana karya foto yang dihasilkan dari proses fotografi selain memberi informasi yang cermat, otentik, juga memiliki nilai dokumenter yang tinggi yang dapat menjadi media penyampai pesan kepada siapapun yang melihatnya yang dalam hal ini adalah mengenai kelestarian lingkungan.

Pembelajaran fotografi berbasis ecohistory akan berjalan dengan efektif dan berkualitas apabila didukung dengan metode media yang tepat. Dari berbagai jenis media, multimedia dipilih dalam penelitian ini karena sesuai dengan bidang mata kuliah yang dipilih yaitu fotografi dimana mata kuliah ini diharapkan dapat menghasilkan output berupa produk hasil fotografi yang lebih interaktif.

Terdapat beragam definisi tentang multimedia. Hal ini dipengaruhi oleh beragamnya ruang lingkup aplikasi serta multimedia itu sendiri. Multimedia bermakna teks dan grafik sederhana saja, melainkan juga suatu media yang dilengkapi dengan suara, animasi, video, dan interaksi. Artinya penggunaan multimedia melibatkan berbagai indera yang berbeda. Multimedia mengkombinasi teks, seni, suara, gambar, animasi, dan video yang disampaikan dengan komputer dan dapat disampaikan secara interaktif. Multimedia juga dapat didefinisikan sebagai keterpaduan diantara berbagai media teks, gambar, video, dan animasi dalam satu media digital yang mempunyai kemampuan untuk interaktif, umpan balik dan informasi dengan cara yang non linear (Munir, 2012). Hal ini sesuai dengan Suyanto (2003) yang menjelaskan multimedia adalah pemanfaatan komputer untuk membuat dan menggabungkan teks, grafik, audio, gambar bergerak (video dan animasi) dengan menggabungkan link dan tool yang memungkinkan pemakai melakukan navigasi, berinteraksi, berkreasi, dan berkomunikasi.

Multimedia Interaktif merupakan suatu alat yang dilengkapi dengan alat control yang dapat dioperasikan oleh penggunanya dalam memilih sesuatu yang dikehendaki. Contoh Multimedia interaktif adalah multimedia pembelajaran interaktif (pembelajaran berbasis multimedia interaktif), aplikasi game dan lain-lain.

\section{METODEPENELITIAN}

Penelitian ini merupakan jenis penelitian dan pengembangan pendidikan yaitu mengembangkan multimedia fotografi berbasis ecohistory yang menumbuhkan karakter peduli lingkungan menggunakan pengembangan dengan model meliputi 4-D yaitu Define, Design, Develop, and Dessiminate (Thiagarajan, Semmel \& Semmel, 1974).

Subjek validasi produk adalah dua orang ahli yaitu ahli materi dan ahli media. Sedangkan subjek uji coba produk multimedia pembelajaran berbasis ecohistory dalam penelitian pengembangan ini adalah mahasiswa program studi Pendidikan Informatika Universitas Ivet.

Tahap pertama dalam penelitian ini adalah tahap pengumpulan informasi tentang tingkat sikap kepedulian mahasiswa terhadap lingkungan. Aspek sikap yang diteliti meliputi afektif, kognitif dan konatif. Berdasarkan data hasil penelitian pendahuluan tentang sikap peduli lingkungan 
dengan menggunakan instrumen selfassessment terhadap mahasiswa Universitas Ivet diketemukan fakta bahwa aspek afektif dan kognitif mahasiswa tergolong tinggi namun pada aspek konatif tergolong cukup. Nilai konatif yang tergolong cukup mengindikasikan bahwa siswa memiliki pengetahuan dan kecenderungan pro terhadap lingkungan namun memiliki kecenderungan belum menerapkan sepenuhnya perilaku peduli lingkungan tersebut dalam kehidupan. (Rani, 2019).

Tahap kedua yang dilakukan adalah merancang perangkat pembelajaran beserta multimedia berbasis ecohistory. Rancangan perangkat meliputi Rencana Pelaksanaan Semester (RPS), silabus, lembar kerja, instrumen penilaian dan multimedia fotografi berbasis ecohistory. Multimedia pembelajaran berbasis ecohistory yang dikembangkan menggunakan aplikasi kvisoft flip book. Keseluruhan perangkat ini kemudian disebut dengan draf 1.

Pada tahap ketiga yaitu develop, dikembangkan multimedia ecohistory yang dapat menumbuhkan karakter peduli lingkungan (draf 1). Perangkat ini kemudian divalidasi oleh dua validator ahli materi dan media. Masukan dari validator digunakan untuk merevisi perangkat yang dikembangkan yang selanjutnya disebut draf 2. Draf 2 diterapkan di kelas uji coba dan kemudian dianalisis. Hasil analisis digunakan untuk menyempurnakan perangkat pembelajaran (perangkat final). Pada penelitian ini tidak dilakukan penyebarluasan (disseminate).

Metode pengumpulan data digunakan melalui angket, lembar observasi, lembar validasi dan tes. Angket digunakan untuk menganalisis keberhasilan penerapan multimedia berbasis ecohistory dan untuk mengetahui karakter peduli lingkungan pada diri mahasiswa. Lembar observasi digunakan untuk mengetahui keaktifan mahasiswa dan munculnya indikator karakter peduli lingkungan selama proses pembelajaran. Validitas perangkat diuji dengan menggunakan lembar validasi yang diisi oleh dua orang ahli. Sedangkann tes digunakan untuk menilai tingkat pencapaian hasil belajar mahasiswa selama perkuliahan.

\section{HASIL DAN PEMBAHASAN Gambaran Produk yang Dikembangkan}

Produk yang dikembangkan adalah multimedia interaktif yang dibuat dengan dengan menggunakan aplikasi Kvisoft Flip Book Maker. Kvisoft Flip Book Maker adalah jenis perangkat lunak flip untuk mengkonversi file PDF ke bentuk digital. Software ini paling mudah digunakan untuk mengubah PDF ke flash flip book dengan efek lipatan halaman digital. Halaman ini memiliki fungsi menjadikan teks dan gambar tersebut dalam informasi digital baik dalam format swf, sexe, .html, email atau dijadikan screen saver. Tidak hanya teks, Kvisoft Flip book Maker mampu mengintegrasikan tayangan suara, grafik, gambar, animasi, maupun film, sehingga informasi yang disajikan lebih kaya dibandingkan dengan buku teks bahan ajar. Flash flip book merupakan buku elektronik berbasis multimedia. Flash flip book dapat memuat file berupa teks, gambar bergerak atau animasi serta dapat memuat video. Dalam penggunaannya terdapat interaksi antara media dengan yang mengoprasikannya. Interaksi tersebut merupakan kegiatan pengguna dalam memutar video dan membalikkan halaman sesuai keinginan pengguna. Dengan demikian flash flip book dapat dikatakan sebagai multimedia interaktif.

Multimedia yang dikembangkan memuat materi tentang fotografi, referensireferensi yang relevan, pertanyaanpertanyaan dan tugas yang harus dikerjakan oleh mahasiswa. Kelebihan dari multimedia interaktif ini adalah mahasiswa dapat 
mengoperasikan produk secara mandiri dan dapat dioperasikan secara offline sehingga dapat diakses kapanpun dan dimanapun (Wibowo \& Pratiwi, 2018).

Multimedia yang dikembangkan memiliki fitur antar lain bookmarks, table of content, sound, print, thumbnails, zoom in, zoom out dan fullscreen. Adapun spesifikasi komputer yang dapat digunakan untuk instalasi program ini harus memiliki spesifikasi 1) sistem operasi Microsoft Windows XP, Vista, 7 atau 8, 2) minimal prosesor dual core, 3) minimal kapasitas 512 MB 4) browser yang digunakan adalah mozilla firefox, google chrome, internet explorer dan 5) menggunakan flash player Adobe Flash 10/11 atau lebih.

Melalui pembelajaran dengan menggunakan multimedia ini mahasiswa diarahkan untuk membuat karya seni fotografi kota dan menganalisisnya dari sisi ekohistoris sehingga mahasiswa dapat merefleksi perilakunya terhadap lingkungan dengan membandingkan kondisi lingkungan di masa lalu dan masa kini. Sehingga mahasiswa mendapatkan makna dari hasil fotografi yang mereka hasilkan. Berikut contoh tampilan medianya:

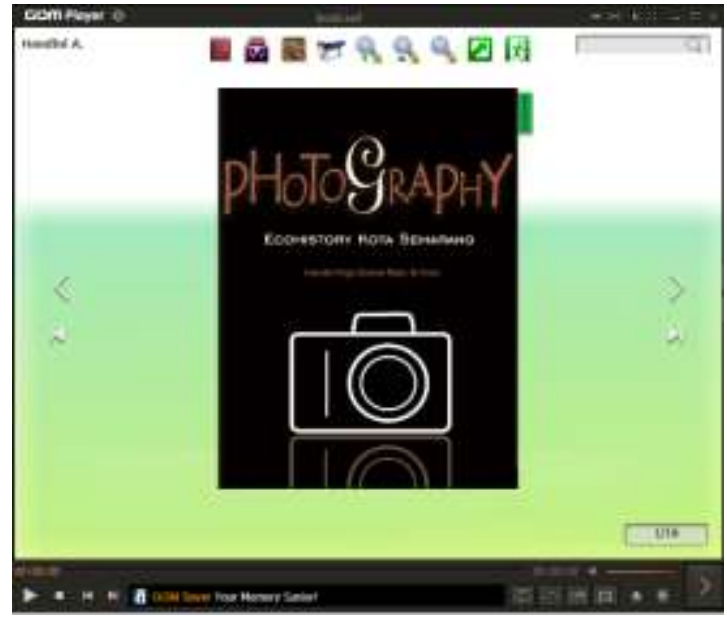

Gambar 1. Tampilan halaman utama media

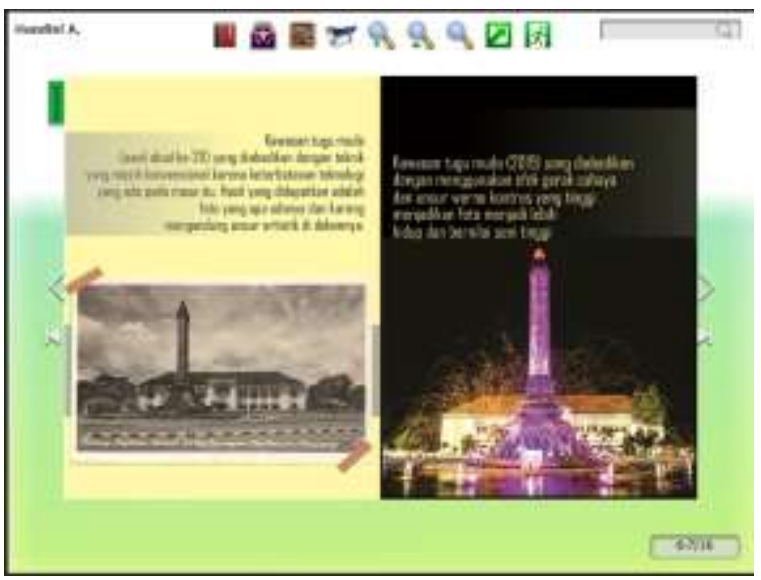

Gambar 2. Contoh obyek fotografi salah satu tempat di Kota Semarang jaman dulu dan sekarang

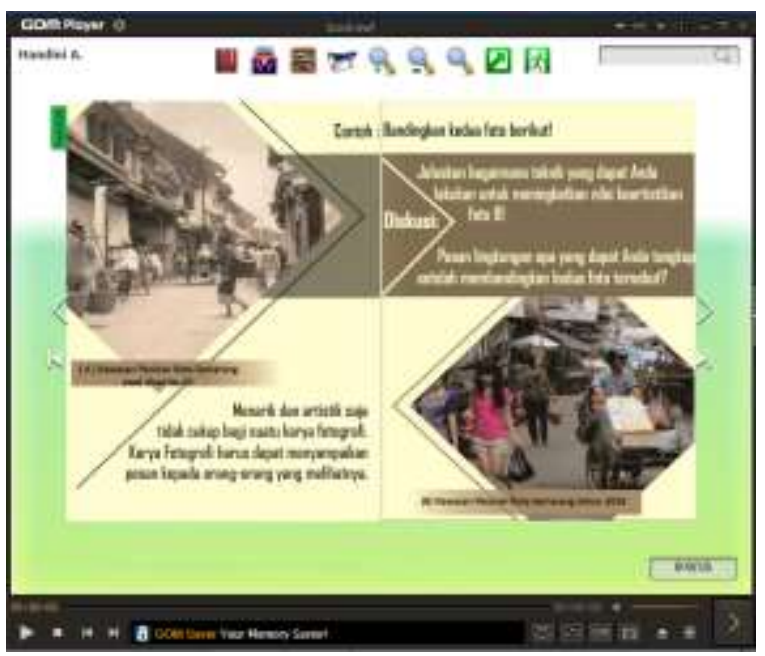

Gambar 3. Tampilan media sebagai bahan diskusi siswa

\section{Kalayakan Media}

Uji kelayakan multimedia dilakukan melalui validasi ahli yaitu ahli media dan perangkat pembelajaran. Skor validasi dinyatakan dalam skala likert 1-4. Adapun kriteria validasi dapat dilihat pada Tabel 1 .

Tabel 1. Kriteria validasi

\begin{tabular}{ll}
\hline Skor Kalitas & Kriteria Kelayakan \\
\hline $3,26<\mathrm{x} \leq 4,00$ & Valid \\
\hline $2,51<\mathrm{x} \leq 3,26$ & Cukup Valid \\
\hline $1,76<\mathrm{x} \leq 2,51$ & Kurang Valid \\
\hline $1,00<\mathrm{x} \leq 1,76$ & Tidak Valid \\
\hline
\end{tabular}


Berdasarkan hasil validasi, tergolong valid dengan skor 3,62. Skor hasil multimedia dan perangkat yang digunakan validasi dalam dapat dilihat pada Tabel 2.

Tabel 2. Hasil Validasi Materi Ahli

\begin{tabular}{lll}
\hline No & Validator 1 & Validator 2 \\
\hline Tampilan Program & & \\
\hline 1. $\quad$ Tampilan Desain & 4 & 4 \\
\hline 2. $\quad$ Tampilan pada layar & 4 & 4 \\
\hline 3. $\quad$ Pemakaian kata dan bahasa & 3 & 4 \\
\hline $4 . \quad$ Kualitas gambar yang ditampilkan & 3 & 3 \\
\hline 5. Informasi gambar/foto & 3 & 4 \\
\hline Kualitas Teknis & & \\
\hline 1. $\quad$ Pengoprasian perangkat & 4 & 4 \\
\hline 2. $\quad$ Reaksi pemakaian & 3 & 4 \\
\hline 3. Kemutakhiran & 4 & 3 \\
\hline Skor Validitas & \multicolumn{2}{l}{3,62} \\
\hline
\end{tabular}

Selain hasil kuantitatif, ahli juga memberikan beberapa saran yaitu terkait dengan penambahan informasi yang lebih lengkap tentang materi perkuliahan fotografi dan perbaikan tampilan multimedia agar lebih artistik. Hasil validasi ahli kemudian dijadikan dasar untuk perbaikan multimedia.

\section{Hasil Uji Coba}

Berdasarkan hasil uji coba pertama didapatkan beberapa hal yang perlu diperbaiki antara lain media yang dikembangkan masih cenderung memberikan informasi secara searah dari dosen ke mahasiswa sehungga perlu ditambahkan pertanyaan pertanyaan kritis, tugas, link web dan video agar multimedia menjadi semakin interaktif. Pada hasil uji coba juga dilakukan revisi salah satu gambar karena resolusi yang kurang baik.

Hasil observasi selama proses pembelajaran menunjukkan muculnya indikator-indikator sikap kepedulian terhadap lingkungan. Indikator peduli lingkungan yang diamati selama pembelajaran meliputi aspek motivasi, pengetahuan dan keterampilan.

Indikator karakter peduli lingkungan yaitu motivation (motivasi) meliputi aspek antusiasme dan keaktifan mahasiswa dalam kegiatan diskusi dan tanya jawab yang berhubungan dengan isu-isu lingkungan selama pembelajaran. Dari hasil pengamatan dengan lembar observasi diketahui bahwa aspek motivasi tergolong tinggi dengan skor $83,33 \%$. Hal tersebut sesuai hasil penelitian terdahulu yang menyebutkan bahwa media pembelajaran dalam proses belajar mengajar dapat membangkitkan minat dan keinginan yang baru, motivasi dan rangsangan kegiatan belajar, dan bahkan membawa pengaruhpengaruh psikologis sehingga akan membantu keefektifan proses pembelajaran dalam penyampaian pesan dan isi pelajaran pada saat itu (Daryanto, 2013). Selain membangkitkan motivasi dan minat siswa, media pembelajaran juga dapat membantu mahasiswa meningkatkan pemahaman, menyajikan data dengan menarik dan memadatkan informasi. Ramdania (2013) dan Mureiningsih (2014) bahwa penggunaan media Flash Flipbook dapat menambah motivasi belajar dan juga dapat mempengaruhi prestasi atau hasil belajar. Penggunaan Flipbook juga dapat meningkatkan pemahaman dan meningkatkan pencapaian hasil belajar (Nazeri, 2013).

Aspek knowledge (pengetahuan) tergolong tinggi dengan skor hasil observasi sebesar $80 \%$. Sebagian mahasiswa mampu mendeskripsikan perubahan lingkungan yang 
terjadi dan permasalahan yang dihadapi pada saat ini. Berdasarkan hasil kuesioner, mayoritas mahasiswa berpendapat bahwa permasalahan yang lingkungan yang dihadapi saat ini terutama adalah masalah sampah dan polusi udara khususnya di kota besar. Selain itu adalah daerah resapan air yang semakin berkurang sehingga menyebabkan banjir dan pemanasan global yang menyebabkan kenaikan permukaan air laut.

Aspek skill (keterampilan) tergolong sangat tinggi dengan pencapaian $87.5 \%$. Mahasiswa telah mampu mengidentifikasi perubahan lingkungan yang terjadi berdasarkan hasil foto yang telah dihasilkan dan mampu mendeskripsikan secara rinci terkait perubahan tersebut. Beberapa perubahan yang dapat teridentifikasi dari hasil foto antara lain ledakan penduduk, sampah plastik, daerah resapan air, polusi udara, polusi air dan polusi udara.

Berdasarkan hasil angket, persepsi mahasiswa terhadap pembelajaran mata kuliah fotografi berbasis ecohistory menunjukkan skor $89,9 \%$. Hal tersebut menunjukkan bahwa mahasiswa memiliki respon sangat baik terhadap pembelajaran. Selaras dengan hal tersebut, pada pembelajaran berbasis ecohistory mahasiswa cenderung lebih aktif dan kritis. Berdasarkan hasil angket diketahui bahwa mahasiswa menunjukkan rasa peduli lingkungan yang tinggi. Hal ini dibuktikan dengan skor angket karakter peduli lingkungan dengan skor $80,25 \%$. Hasil positif yang tampak antara lain adalah perubahan perilaku mahasiswa menjadi lebih baik dalam memperlakukan lingkungan. Hal tersebut terlihat dari jawaban mahasiswa tentang isu-isu lingkungan antara lain masalah plastik, bahan

\section{DAFTAR PUSTAKA}

Ardanita, B.A, Utaya, S \& Ruja, I.N. 2017. Membentuk Karakter Peduli bakar, pencemaran udara, sumber daya air dan Sumber Daya Alam Hayati yang tergolong positif. Misalnya tentang jawaban pertanyaan-pertanyaan tentang permasalahan sampah, mayoritas mahasiswa sangat tertarik untuk melakukan hal-hal yang dapat mengatasi permasalahan tersebut diantaranya menggunakan produk ramah lingkungan, mengurangi penggunaan plastik belanja dan mebuang sampah pada tempatnya. Mengenai pertanyaan tentang bahan bakar, mahasiswa cenderung lebih memilih bahan bakar ramah lingkungan dan menghemat penggunaan bahan bakar fosil. Beberapa hal di atas menunjukkan adanya kepedulian tinggi mahasiswa terhadap kelestarian lingkungan.

\section{PENUTUP}

Berdasarkan hasil analisis data yang diperoleh maka dapat disimpulkan bahwa: 1) Multimedia fotografi berbasis ecohistory yang dikembangkan untuk menumbuhkan karakter peduli lingkungan termasuk dalam kategori valid dengan skor 3,62 dengan skala penilaian 1-4, aspek tampilan program mendapatkan skror rata-rata 3,60 sedangkan dari kualitas teknis multimedia yang dikembangkan mendapatkan skor penilaian 3,67 dari ahli 2) respon mahasiswa terhadap multimedia fotografi berbasis ecohistory yang dikembangkan adalah positif. Hal tersebut dapat terlihat dari 89,9\% mahasiswa memberikan respon positif terhadap multimedia yang dikembangkan. Berdasarkah hasil penelitian, saran yang dapat diberikan untuk perbaikan multimedia adalah dalam hal tampilan multimedia dan penambahan materi terkait fotografi dengan lebih lengkap.

Lingkungan Melalui Komunitas Pelajar Peduli Lingkungan Hidup 
(KPPH). Proseeding Seminar TEP \& PDs. 7(4), 969-974

Daryanto. 2013. Inovasi Pembelajaran Efektif. Bandung: Yrama Widya

Gunawan, Z. 2016. Pengembangan Program Adiwiyata dalam Mewujudkan Sekolah Peduli dan Berbudaya Lingkungan. Pedagogik; Jurnal Pendidikan, Vol. 3, No.2 Januari-Juni 2016. http://jurnal. iainuruljadid.ac.id/index.php/pedago gikindex.php/pedagogik/article/ view/15. (PDF). (Online), diakses pada 17 Maret 2017.

Kaiser, F. G., Oerke, B., \& Bogner, F. X. (2007). Behavior- based environmental attitude : development of an instrument for adolescents, 27, 242-251.https:/ /doi.org/ 10.1016/ j.jenvp.2007. 06.004

Munir. 2012. Multimedia: Konsep \& Aplikasi dalam Pendidikan. Bandung: Alfabeta

Mureiningsih, E.S. 2014. Meningkatkan Hasil Belajar Siswa Melalui Media Pembelajaran Multimedia Interaktif. Jurnal Madaniyah, 7, 214-229

Nazeri. 2013. "Penggunaan e-FlipBook dalam Topik Elektrik dan Elektronik: Inovasi dalam Pengajaran Reka Bentuk dan Teknologi PISMP RBT". Prosiding Seminar Penyelidikan IPG Zon Timur (1), 1

Thiagarajan, S. Semmel, D.S \& Semmel, M.I. 1974. Instructional Development for Training Teachers of Exceptional Children. Indiana: Indiana University Bloomberg

Nopriyanti \& Sudira, P. 2015. Pengembangan Multimedia Pembelajaran Interaktif Kompetensi Dasar Pemasangan Sistem Penerangan dan Writing Kelistrikan di SMK. Jurnal Pendidikan Vokasi. 5(2), 222-235

Purwanti, D. 2017. Pendidikan Peduli Lingkungan dan Implementasinya. DWIJACENDEKIA: Jurnal Riset Pedagogik, 1(2), 14-20

Ramdania, D. R. 2013. "Penggunaan Media Flash Flip Book Dalam Pembelajaran Teknologi Informasi Dan Komunikasi Untuk Meningkatkan Hasil Belajar Siswa”. Artikel Ilmiah Tugas Akhir. Bandung. UPI

Rani, H.A.D. 2019. Pengembangan Instrumen Self-Assesment Berbasis Web Untuk Menilai Sikap Peduli Lingkungan. Proseeding Seminar Nasional Edusainstek

Suyanto, M. 2003. Multimedia Alat untuk Meningkatkan Keunggulan Bersaing. Yogyakarta: Andi.

Wibowo, E \& Pratiwi, D.D. 2018. Pengembangan Bahan Ajar Menggunakan Aplikasi Kvisoft Flipbook Maker Materi Himpunan. Desimal: Jurnal Matematika, 1(2), $147-156$ 